\title{
Transformacje w interakcjach: przykład relacji między rodzicami i dziećmi LGBT+
}

\begin{abstract}
Abstrakt
Celem niniejszego tekstu jest rekonstrukcja procesu transformacji, jaki zachodzi $\mathrm{w}$ relacji rodzica z dzieckiem o nienormatywnej orientacji seksualnej lub tożsamości płciowej (LGBT+). Z uwagi na to, że przekształcanie siebie oraz rzeczywistości ma miejsce w toku podejmowanych aktywności, zatem z komunikowanych doświadczeń biograficznych narratorów zidentyfikowane zostały aktywności mentalne, afektywne oraz performatywne, a także związki między nimi. W badaniu uczestniczyli rodzice osób LGBT+ z terenu Polski, którzy byli dobierani zgodnie z procedurą kuli śnieżnej. Dane empiryczne zostały zgromadzone za pośrednictwem techniki wywiadu narracyjnego i opracowane w toku jakościowej indukcyjnej analizy tematycznej. Odtworzony na tej podstawie proces transformacji obejmował zidentyfikowane zmiany mentalne w zakresie postrzegania i rozumienia rzeczywistości, modyfikacje afektów, które dynamizowały aktywność podmiotu oraz czynności przeobrażających świat. Transformacje wyrażały się zarówno w postrzeganiu i przekształcaniu rzeczywistości, jak też działającego w niej podmiotu.
\end{abstract}

Słowa kluczowe: transformacje, wywiad narracyjny, rodzice, osoby LGBT+, coming out.

\section{Transformations in Interactions: the Example of the Relationship between Parents and LGBT + Children}

\begin{abstract}
The aim of this paper is to reconstruct the transformation process that takes place in the parent-child relationship with a non-normative sexual orientation or gender identity (LGBT+). Due to the fact that the transformation of oneself and reality takes place in the course of undertaken activities, mental, affective and performative activities as well as relationships between them were identified from the communicated
\end{abstract}

\footnotetext{
* Uniwersytet Łódzki.

Artykuł otrzymano: 2.02.2021; akceptacja: 11.03.2021.
} 
biographical experiences of the narrators. Parents of LGBT+ people from Poland who were selected according to the snowball procedure participated in the study. Empirical data was collected through the narrative interview technique and developed through qualitative inductive thematic analysis. The transformation process recreated on this basis included the identified mental changes in the perception and understanding of reality, modifications of affects that dynamized the activity of the subject and activities transforming the world. The transformations were expressed both in the perception and transformation of reality, as well as the subject acting in it.

Keywords: transformations, narrative interview, parents, LGBT + people, coming out.

\section{Wprowadzenie}

W polskim dyskursie publicznym upowszechniany jest schematyczny i jednostronny obraz osób tworzących społeczność LGBT+1, który kształtuje opinię publiczną i legitymizuje uprzedzenia wobec tej mniejszości. Generalizacje traktowane są jak odzwierciedlenie stanu faktycznego i nie budzą potrzeby weryfikacji czy krytycznego namysłu. Równocześnie przekonania te stają się poznawczym komponentem uprzedzeń wymierzonych w konkretną zbiorowość, którym często towarzyszy negatywny stosunek emocjonalny oraz dyskryminujące zachowania. Analiza wyników badań na temat uprzedzeń wobec osób nienormatywnych ze względu na orientację seksualną ${ }^{2}$ lub tożsamość płciową ${ }^{3}$ wskazuje, że pojawiają się one nie tylko ze strony osób heteroseksualnych ${ }^{4}$ i cispłciowych ${ }^{5}$, ale również w obrębie samej społeczności LGBT+, tworząc wewnątrz mniejszości grupy bardziej lub mniej uprzywilejowane (Worthen 2012: 703 i nast.). Można wskazać różnorodne przyczyny kształtowania się negatywnych postaw wobec osób nieheteronormatywnych, skorelowane z płcią i orientacją seksualną. Uważa się, że styl życia osób homoseksualnych (Fish, Rye 1991) i biseksualnych (Worth 2003) wiąże się z ryzykiem zakażenia wirusem HIV; heteroseksualni mężczyźni obawiają się seksualnych propozycji i zalotów ze strony innych mężczyzn (Eliason 1997), natomiast mają bardziej pozytywny stosunek do homo- i biseksualnych kobiet, ponieważ traktują je jak obiekt seksualny (Raja, Stokes 1998), podobnie heteroseksualne kobiety mogą postrzegać homoseksualnych mężczyzn (Eliason, Raheim 1996); negatywne postawy budzi ekspresja płciowa, która wykracza poza uznane społecznie normy i wzory

\footnotetext{
1 Skrótowiec LGBT odnosi się do społeczności złożonej z osób nieheteronormatywnych (m.in. lesbijek, gejów, osób biseksualnych i transpłciowych), które tworzą mniejszość niewpisującą się w dominujący obraz seksualności i płci; plus oznacza pokrewne społeczności, które rozszerzają spektrum seksualności i tożsamości płciowych.

2 Orientacja seksualna to pociąg romantyczny lub/i seksualny wobec osób o określonej płci, w związku z czym można wyróżnić orientację heteroseksualną, homoseksualną, biseksualną oraz aseksualną.

3 Tożsamość płciowa wskazuje na odczuwaną przez osobę przynależność do określonej płci (nie musi być zgodna z płcią biologiczną rozpoznaną przy urodzeniu i wskazaną w akcie urodzenia).

4 Osoba heteroseksualna angażuje się emocjonalnie i seksualnie w relacje z osobami płci przeciwnej.

5 Osoba cispłciowa to człowiek, którego tożsamość płciowa zgadza się z płcią metrykalną.
} 
zachowań wpisane w płeć (Gordon, Meyer 2007); brak akceptacji dotyczy również związków osób LGBT+, ponieważ podważają heteronormatywność ${ }^{6}$ i cisnormatywność ${ }^{7}$ (Kimmel 2009). Płeć oraz inne zmienne socjodemograficzne, takie jak wiek, wykształcenie, wielkość miejscowości zamieszkania, religijność czy poglądy polityczne korespondują z uprzedzeniami wobec mniejszości seksualnych. Są one postrzegane jako zagrożenie dla tradycji, religii, wartości i światopoglądu bądź zasobów i statusu grupy dominującej (Górska, Mikołajczak 2015: 189-194).

Obok jawnej niechęci, motywowanej tradycją kulturową oraz przekonaniami religijnymi, które umacniają stanowisko o nienaturalności i grzeszności innej niż heteroseksualna ekspresji płciowej, pojawia się nowy rodzaj uprzedzeń (McConahay 1986), który neguje istnienie dyskryminacji osób LGBT+ w życiu społecznym, tym samym podważając potrzebę dokonywania zmian w zakresie dostępnych im praw, a także oskarża o zawłaszczanie przez nie przestrzeni publicznej poprzez „afiszowanie się” („obnoszenie się”) ze swoją seksualnością (Górska, Mikołajczak 2015: 181-182). Wskazane powyżej stereotypy oraz uprzedzenia są społecznie reprodukowane i uznawane jako wiarygodne m.in. na mocy ich powszechności, zgodności z własnymi przekonaniami czy brakiem krytycznego namysłu nad nimi. W ich efekcie rodzi się określony sposób postrzegania inności, a także nastawienie emocjonalne wobec reprezentantów mniejszości. Rodzice osób LGBT+ są zmuszeni do zmierzenia się z takim punktem widzenia, kiedy sytuacja zaczyna dotyczyć ich bezpośrednio.

\section{Coming out dziecka jako punkt zwrotny w życiu rodzica}

Osoba nienormatywna ze względu na orientację seksualną lub tożsamość płciową w określonym momencie swojego życia może poinformować o tym fakcie innych, dokonując coming outu ${ }^{8}$. Badania wskazują, że jest to niezwykle trudny dla niej moment i w pierwszej kolejności wybiera osoby, które postrzega jako otwarte i akceptujące. Najczęściej są to przyjaciele (D’Augelli, Patterson 2001) lub rodzeństwo, a dopiero $\mathrm{w}$ dalszej kolejności rodzice. Zdarzają się sytuacje, kiedy rodzice (zwykle matki) reagują pozytywnie na wiadomość przekazaną przez ich dziecko, zapewniając mu wsparcie i akceptację (D’Augelli 2005; Savin-Williams, Dubé 1998), jednak znacznie częściej osoby LGBT+ są bardzo ostrożne w kontakcie $\mathrm{z}$ rodzicami, odraczają czas rozmowy z nimi z obawy przed pogorszeniem się

\footnotetext{
${ }^{6}$ Heteronormatywność to kulturowo reprodukowane założenie, że wszyscy ludzie są heteroseksualni i wpisują się $\mathrm{w}$ binarny porządek płci. Na tej podstawie domyślnym podmiotem życia społecznego staje się osoba heteroseksualna, a formą zaangażowania emocjonalnego i seksualnego relacja między kobietą i mężczyzną.

7 Cisnormatywność - założenie, że wszyscy ludzie są cispłciowi i jednoznacznie identyfikują się z płcią metrykalną.

${ }^{8}$ Coming out („wyjście z szafy”) polega na ujawnieniu się jako osoba LGBT+ (lesbijka, gej, osoba biseksualna, transpłciowa czy inna osoba nienormatywna) w sferze prywatnej i publicznej.
} 
relacji, odrzuceniem czy przemocą (Savin-Williams 1989: 3). Jak się okazuje, obawy te nie są bezpodstawne i mogą prowadzić do rzeczywistych, negatywnych konsekwencji, m.in. bezdomności (Robinson 2018).

Rodzicielskie reakcje na coming out są najczęściej rekonstruowane z perspektywy dzieci (D’Augelli, Hershberger, Pilkington 1998; Savin-Williams 1989) lub rzadziej samych rodziców (Ben-Ari 1995; Muller 1987). W odpowiedzi na informację o nienormatywnej orientacji seksualnej lub tożsamości płciowej dziecka zwykle pojawia się silna reakcja emocjonalna, szok, niedowierzanie, zakłopotanie, wstyd, smutek, panika, ale też strach o bezpieczeństwo dziecka czy poczucie winy (Ben-Ari 1995; LaSala 2000). Proces dostosowywania się do nowej sytuacji zależny jest od indywidualnych cech zaangażowanych osób, jakości relacji między nimi oraz w całej rodzinie. Badania wskazują, że reakcja rodzica może być warunkowana m.in. jego płcią, miejscem zamieszkania, wyznawaną religią, statusem dziecka, wiekiem, w jakim dokonało coming outu, wcześniejszymi więziami, zdolnością adaptacji oraz bliskością i wzajemnym wsparciem w rodzinie (Heatherington, Lavner 2008).

Coming out dziecka może stanowić dla rodzica znaczące wydarzenie życiowe, punkt zwrotny, który rozpoczyna proces transformacji, m.in. w wymiarze tożsamości (Strauss 1969) czy podejmowanych interakcji (Baxter 2004), wiąże się z poczuciem istotnej, nieprzewidzianej wcześniej zmiany we własnej biografii. Często okazuje się kryzysem lub wydarzeniem krytycznym, które z subiektywnego punktu widzenia wiąże się ze stratą, rozczarowaniem i porażką, odkryciem nieadekwatności własnych oczekiwań i nadziei, a także zakłóceniem codziennej rutyny (Park 2010) czy załamaniem dotychczasowego sposobu działania. W konsekwencji prowadzi do reinterpretacji rzeczywistości, oceny sytuacji w kontekście nowych doświadczeń, redefinicji siebie i własnej roli społecznej, innych osób oraz relacji $\mathrm{z}$ nimi.

\section{Proces godzenia się z nową sytuacją}

Coming out członka rodziny wywołuje szereg następstw w jej funkcjonowaniu, co wyraźnie akcentuje perspektywa odwołująca się do teorii systemów. Zgodnie z tym ujęciem, w odpowiedzi na kryzys wywołany coming outem rozpoczyna się sekwencyjny, linearny proces adaptacji do nowej sytuacji. Rodzina przechodzi przez pięć kolejnych faz: świadomość podprogowa, wstrząs, dostosowanie, rozkład, integracja (DeVine 1984), które rozwijają się równolegle do tożsamości osoby nieheteronormatywnej. Odmienny punkt widzenia, akcentujący relacyjność procesu coming outu podkreślają dwie inne koncepcje: „przezroczystej szafy” i „rodzinnej szafy” (Švab, Kuhar 2014). Kategoria „przezroczystej szafy” odnosi się do sytuacji, w których nienormatywność dziecka zostaje uświadomiona członkom jego rodziny, natomiast w odpowiedzi stanowią oni reguły zabraniające dyskutować czy rozpowszechniać 
ten fakt, odmawiają też jej uznania i zmierzenia się z konsekwencjami, jakie ze sobą niesie. Wejście do „rodzinnej szafy” polega na tym, że rodzina ukrywa seksualność lub tożsamość dziecka przed osobami spoza swojego wąskiego grona (dalszą rodziną, przyjaciółmi, znajomymi), często z obawy przed ich uprzedzeniami lub stygmatyzacją wszystkich jej członków.

Proces godzenia się rodzica z nową wiedzą o dziecku, analizowany z perspektywy osobistych doświadczeń, bardzo często odnoszony jest do psychologicznego modelu kolejnych etapów przeżywania żałoby (Kübler-Ross 1969), kiedy po pierwszym szoku pojawia się zaprzeczenie, następnie gniew i bunt, targowanie się, depresja oraz akceptacja (Savin-Williams, Dubé 1998). Badania fenomenologiczne identyfikują natomiast zagadnienia, które pojawiają się w doświadczeniach rodzicielskich po coming oucie. Rodzice osób LGBT+ wskazują m.in., że poszukują przyczyn nienormatywności swojego dziecka (często w sobie), opłakują heteroseksualne wyobrażenia i oczekiwania dotyczące przyszłego życia swoich dzieci (ślub, wnuki), towarzyszy im obawa o ich bezpieczeństwo, a także autorefleksja (Bernstein 1990; Saltzburg 2004).

Złożony proces pracy rodzica osoby LGBT+ nad tożsamością prezentują badania uwzględniające perspektywę symbolicznego interakcjonizmu. Rodzicielska praca interpretacyjna koncentruje się na rekonstrukcji znaczeń związanych z normatywnym postrzeganiem ról płciowych, seksualności, heteroseksualnej rodziny i rodzicielstwa. Celem pracy normalizacyjnej jest zakwestionowanie piętna przypisanego społeczności LGBT+ (Fields 2001). Inny sposób pracy nad tożsamością odwołuje się do procesu rodzicielskiego coming outu. W narracjach tych rekonstruowana jest sekwencja zdarzeń zapoczątkowanych przez coming out dziecka, który był zaskoczeniem, ale równocześnie uświadamiał brak wiedzy na temat homoseksualności czy konsekwencji homofobii. Przeżycie to uruchamiało potrzebę poszukiwania wiedzy, ale też wsparcia i budowania wspólnoty z innymi osobami znajdującymi się w podobnej sytuacji. W konsekwencji rekonstrukcji tożsamości rodzice stawali się aktywistami i rzecznikami swoich dzieci, budowali swój obraz jako dumnych heteroseksualnych sojuszników społeczności LGBT+ (Broad 2002).

\section{Założenia metodologiczne oraz rama interpretacyjna badań własnych}

Przegląd literatury przedmiotu pozwolił zrekonstruować kontekst, zdarzenie inicjujące, jak również proces godzenia się rodziców z coming outem dzieci oraz związanymi z nim konsekwencjami, równocześnie wskazał luki, które pozwoliły zaprojektować prezentowane w niniejszym tekście badania.

Celem niniejszego artykułu stała się identyfikacja aktywności mentalnych, afektywnych oraz performatywnych, a także związków między nimi, które składają się na proces transformacji zachodzących $\mathrm{w}$ relacji rodzica $\mathrm{z}$ dzieckiem LGBT+. 
Rozpoznane związki między aktywnościami pozwalają odtworzyć napięcia pojawiające się pomiędzy wiedzą, informacjami, światopoglądem a emocjami i uczuciami oraz podejmowanym działaniem. Perspektywa rodziców osób LGBT+ rzadko jest przedmiotem analiz, dlatego też ta grupa stała się próbą badawczą.

Dane analizowane w niniejszym tekście pochodzą z badań mieszczących się w nurcie jakościowych orientacji badawczych, zogniskowanych wokół doświadczeń biograficznych rodziców osób LGBT+. Ich uczestnikami stali się rodzice, którzy są świadomi nienormatywnej orientacji seksualnej lub tożsamości płciowej swojego dziecka i zgodzili się opowiedzieć historię swojego życia, łącznie 28 osób. W większości były to matki (24) zarówno nastoletnich, jak też dorosłych i usamodzielnionych już osób LGBT+ (część z nich miała więcej niż jedno dziecko), w związku z czym występowały między nimi różnice wieku sięgające do 40 lat. Miejscem ich zamieszkania były duże i małe miasta oraz wsie.

Próba badawcza była dobrana zgodnie z procedurą kuli śnieżnej, przy równoczesnym uwzględnieniu strategii minimalnego i maksymalnego kontrastu, wynikającej z teoretycznego doboru próby (Glaser, Strauss 1967). Początkowo za pośrednictwem organizacji pozarządowych i stowarzyszeń działających na rzecz społeczności LGBT+ nawiązywałam kontakt z rodzicami zainteresowanymi udziałem w badaniach, natomiast później kolejne badane osoby lub ich dzieci kontaktowały mnie z potencjalnymi narratorami, którzy nie byli zrzeszeni w żadnej organizacji. Pierwotnie teren badań obejmował wielkie miasta, w których swoje siedziby miały wspomniane wcześniej organizacje pozarządowe i stowarzyszenia, wtórnie jednak obszar ten powiększał się, uwzględniając miejsca zamieszkania informatorów.

Materiał empiryczny (narracje autobiograficzne) został zgromadzony za pośrednictwem techniki wywiadu narracyjnego (Schütze 2008) i koncentrował się na osobistych doświadczeniach rodziców osób LGBT+. Pytanie generujące narrację nie zakreślało obszaru tematycznego do określonego rodzaju przeżyć czy faz życia, obejmując w ten sposób ich kompletną, w sensie gestaltycznym, biografię. Wywiady prowadzone były zgodnie z właściwą technice procedurą metodologiczną i uwzględniały kolejne etapy: rozpoczęcie wywiadu, stymulacja do opowiadania, narracja, pytania, zakończenie wywiadu (Hermanns 1987). Spotkania z narratorami odbywały się we wskazanym przez nich miejscu i trwały od 90 do 360 minut, przy czym średni czas rozmowy to ok. 150 minut. Wywiady za zgodą narratorów zostały zarejestrowane na dyktafonie, a następnie wiernie spisane oraz poddane analizie i interpretacji.

Na potrzeby niniejszego opracowania wykorzystana została procedura analityczna jakościowej indukcyjnej analizy tematycznej, która koncentruje się na treści, a nie na strukturze narracji (Graneheim i in. 2017). Proces analityczny obejmował trzy fazy: przygotowania, porządkowania danych oraz konceptualizacji rezultatów analizy (Elo, Kyngäs 2008). W fazie przygotowania wyselekcjonowane zostały jednostki analizy korespondujące z podjętym zagadnieniem transformacji w relacji 
rodzic - dziecko. Były to fragmenty narracji koncentrujące się na procesie coming outu, jego kontekście oraz konsekwencjach w wymiarze osobistym i relacyjnym. Kolejnym krokiem było porządkowanie danych, które obejmowało kodowanie otwarte, grupowanie i kategoryzowanie oraz abstrahowanie. Ostatnim etapem analizy było wygenerowanie głównych kategorii tematycznych, tworzących pewien model lub system powiązanych ze sobą kategorii pojęciowych, za pomocą którego można zrekonstruować proces transformacji.

Ramą interpretacyjną niniejszego artykułu jest koncepcja transformacji podmiotu, która obejmuje wzajemne związki w zakresie przeobrażeń mentalnych, afektywnych oraz aktywności (Barbier 2015), które zostały zrekonstruowane z narracji rodziców osób LGBT+. Komunikowane w narracji doświadczenie odnosi się do transformacji aktywności podejmowanej przez podmiot, który równocześnie zmienia się w czasie jej trwania i poprzez nią. Zdarzenia pojawiające się w toku życia składają się na doświadczanie aktywności, które pozbawione jest rozpoznania mentalnego, zatem posiada wymiar przedrefleksyjny. Towarzyszą mu afekty, które reorientują aktywność podmiotów, a spostrzeżone stają się odczuciami o pozytywnym lub negatywnym zabarwieniu. $W$ toku interakcji, w czasie których podmioty wzajemnie wywierają wpływ na transformacje swoich aktywności oraz konstruktów sensu, ujawniają się uczucia oddziałujące na konstrukcje mentalne i dyskursywne. Są one związane z konstruowaniem „ja” zarówno w odniesieniu do sposobów myślenia o sobie, jak też bycia uznanym przez innych (Barbier 2020).

Analiza narracji została skoncentrowana na transformacjach będących udziałem rodziców pozostających w relacji ze swoimi dziećmi, jednak przyjęte rozwiązania metodologiczne nie pozwalają na osobistą obserwację tych interakcji (są one reprezentowane dyskursywnie $\mathrm{w}$ opowieściach biograficznych). Z uwagi na brak danych gromadzonych z perspektywy osób LGBT+ (w narracjach rodziców obecna jest interpretacja emocji i zachowań dzieci) rekonstrukcja transformacji powiązanych zachodzących w relacji rodzic - dziecko obejmuje doświadczenie komunikowane przez rodzica, w którym dokonuje on opracowania własnych przeżyć oraz odnosi się do wyobrażonego obrazu swojego dziecka (Barbier 2016). Celowo pominięta została też analiza relacji badacz - badany, która bez wątpienia ma znaczenie dla sposobu komunikowania doświadczenia, ale wymaga odrębnego opracowania.

\section{Sploty aktywności mentalnych, afektywnych oraz performatywnych $w$ procesach transformacji w relacji rodzic - dziecko LGBT+}

Proces transformacji rodziców pod wpływem relacji z dzieckiem o nienormatywnej orientacji seksualnej lub tożsamości płciowej został zrekonstruowany z ich narracji o życiu, w której porządkowali przeszłe doświadczenia i analizowali je z aktualnej 
(dla sytuacji wywiadu) perspektywy. Dokonywali retrospekcji splatających się ze sobą zdarzeń, podejmowanych przez siebie aktywności oraz towarzyszących im emocji, które inicjowały pracę nad doświadczeniem. W niniejszym tekście odtworzone zostały wątki, które stanowią trzon narracji (bez uwzględniania wariantów wynikających ze specyfiki doświadczeń rodzica dziecka należącego do konkretnej grupy mniejszościowej) odzwierciedlające kontekst oraz przebieg procesu transformacji. Należy zaznaczyć, że sam proces nie ma charakteru liniowego, a zidentyfikowane aktywności mentalne, afektywne oraz performatywne splatają się ze sobą, ukazując wzajemne związki i istniejące napięcia w toku procesu transformacji.

\section{(Nie)świadomość cierpienia dziecka}

Odkrywanie nienormatywnej orientacji seksualnej i/lub tożsamości płciowej przez osobę LGBT+ (niekiedy dziecko lub nastolatka) rodzi wiele napięć między jej aktualną oraz pożądaną (przez siebie i innych, również rodziców) reprezentacją siebie. Sytuacja potęgowana jest kontekstem legitymizującym heteronormatywność i cisnormatywność. Dostrzeżenie tych napięć między reprezentacjami tożsamościowymi powoduje cierpienie, które może wyrażać się w przeżywanych emocjach lub zachowaniu. Z uwagi na niejawną w tym czasie komunikację oraz często współwystępujący okres adolescencji, sytuacja ta jest interpretowana przez rodziców zgodnie ze stanem ich aktualnej wiedzy i rozumiana w kontekście młodzieńczego buntu oraz odkrywania przez dziecko własnej tożsamości. Nie mają zatem świadomości, jakie emocje przeżywa ich dziecko, a także, jakie znaczenie mają podejmowane przez nie aktywności. Wszystko nabiera sensu, kiedy wracają pamięcią do wydarzeń z przeszłości z teraźniejszej perspektywy.

(...) To musiał być dla niego naprawdę trudny okres. Nawet nie potrafię sobie wyobrazić, co moje dziecko wtedy przeżywało (...) Teraz, kiedy o tym myślę, zastanawiam się jak mogłam tego nie zauważyć? Przecież dawał mi wyraźne sygnały, jakby przygotowywał mnie na ten moment [coming out - przyp. aut.]. Chyba moją czujność uśpiło to, że przyprowadzał do domu dziewczyny. Nie wierzyłam mu, jak mówił, że to tylko koleżanki (...).

Pewne swojej nienormatywnej orientacji seksualnej i/lub tożsamości płciowej dziecko wysyła liczne sygnały (np. zadaje pytania sondujące, zostawia w widocznym miejscu ulotki lub gazety) nieświadomemu jeszcze rodzicowi i bada jego wyobrażone reakcje w odniesieniu do społeczności osób LGBT+. Przez lata kształtuje obraz tożsamościowy rodzica, zna jego światopogląd i jest w stanie antycypować prawdopodobny sposób zachowania się w rutynowych sytuacjach. Coming out do takich jednak nie należy, a obawę przed odrzuceniem potęgują spontaniczne wypowiedzi rodzica nasycone uprzedzeniami, które głęboko ranią dziecko. 
(...) Przez lata mówiłam wielokrotnie jak bardzo nienawidzę gejów, różne określenia w ich stronę leciały, a ona [córka - przyp. aut.] zamykała się coraz bardziej w sobie. Widziałam, że coś się z nią dzieje, próbowałam dowiedzieć się czegoś, byłam nawet w szkole. Po latach przyznała mi się, że chciała popełnić samobójstwo, a ja nie byłam niczego świadoma. Nie rozumiałam tego, co ona przeżywa przeze mnie (...).

\section{Przeżywanie i (z)rozumienie własnego cierpienia}

Coming out dziecka jest przez nie zaplanowany lub pojawia się spontanicznie jako konsekwencja stopniowo narastającego napięcia albo efekt silnego wzburzenia emocjonalnego. Realizując przygotowany wcześniej scenariusz bądź pod wpływem impulsu, dziecko aktualizuje swój obraz. Niekiedy dzieje się to na odległość (rozmowa telefoniczna, list), ponieważ nie jest gotowe skonfrontować się z nieprzewidywalną reakcją rodzica.

Pierwszą, spontaniczną reakcją matek najczęściej jest płacz lub też nie są w stanie wydobyć z siebie głosu. Wiadomość jest dla nich szokiem i wywołuje tak silne przeżycie, że niektóre osoby mają problem z rekonstrukcją towarzyszących tamtej chwili okoliczności. Reakcja emocjonalna zostaje niekiedy stłumiona lub jest wręcz entuzjastyczna, jeśli pojawi się myśl, że inna może zranić dziecko.

(...) Byłam w ciężkim stanie. Niby na co dzień funkcjonowałam normalnie, ale ogarnęła mnie czarna rozpacz. Nie wiem dlaczego. Myślałam, że serce mi pęknie. Po pracy tylko leżałam i płakałam (...).

Z perspektywy czasu rodzice wstydzą się swoich ówczesnych negatywnych odczuć i sami nie rozumieją własnego postępowania. Równocześnie wyjaśniają, że kierował nimi lęk przed konsekwencjami, jakie niesie ze sobą coming out. Wynikało to m.in. z zakorzenionych $\mathrm{w}$ ich światopoglądzie uprzedzeń, ale też zdawali sobie sprawę ze sposobu, w jaki traktowane są grupy mniejszościowe w społeczeństwie. Mówili, że poszukiwali przyczyn nienormatywności swojego dziecka przede wszystkim w sobie, a także relacji z nim, czemu towarzyszyło cierpienie tożsamościowe.

(...) Zastanawiałam się wielokrotnie: dlaczego mnie to spotkało? Co źle zrobiłam? Może źle go wychowałam, a może to przez to, że jego ojca ciągle nie było w domu (...).

\section{Emocjonalna konfrontacja z wyobrażeniami}

Nowa wiedza o własnym dziecku wywoływała u rodziców automatyczne odniesienia do przyswojonych w toku życia stereotypów i uprzedzeń, a tym samym generowała określone nastawienia emocjonalne. Ponadto konfrontowali się oni z włas- 
nymi wyobrażeniami na temat przyszłości swoich dzieci, odczuwali żal, że nie wezmą udziału w ich ślubie, a rodzice jedynaków podkreślali, że nie będą mieli wnuków.

(...) Teraz się tego wstydzę, ale wtedy to było działanie celowe. Myślałam, że jeszcze jej się zmieni, więc niby przypadkiem mówiłam, że każdy rodzic chce, żeby jego dziecko miało dzieci. Chciałam mieć wnuki (...).

Nastąpiło zawężenie postrzegania dziecka do sfery jego cielesności i seksualności.

(...) Myślenie o swoim dziecku w kontekście seksu jest trudne dla każdego rodzica. Starałam się nie zastanawiać nad stroną techniczną związku jednopłciowego (...).

Przedmiotem troski stało się też jego bezpieczeństwo, relacje i szczęście.

(...) Poczułam ogromny strach o jej bezpieczeństwo. Zastanawiałam się ciągle czy nic jej nie grozi, czy nikt jej nie skrzywdzi przez to, że idzie z dziewczyną (...). Doszłam do wniosku, że nie chcę, żeby do końca życia był sam, a przecież szanse na znalezienie partnera są mniejsze niż w heteroseksualnych związkach (...).

Dużo uwagi rodziców zajmowały też potencjalne reakcje osób, które mogą dowiedzieć się o nienormatywności dziecka (bliższej i dalszej rodziny, przyjaciół, znajomych, sąsiadów). Obawiali się obwiniania siebie, negatywnych reakcji wobec niego, ale też stygmatyzacji całej rodziny. Nie wszyscy byli w stanie ponownie podjąć rozmowę z dzieckiem na temat jego orientacji seksualnej lub transpłciowości, nie wiedzieli też, jak powinni się zachowywać w tej sytuacji. Niektórzy ustalili rygorystyczne reguły rozpowszechniania informacji, np. wśród osób z rodziny, inni budowali strategie kolejnych coming outów albo też zupełnie przestali na ten temat rozmawiać, ignorując nową wiedzę i unieważniając ją.

(...) Od razu powiedziałam, że może być jaka chce, ale żeby te rewelacje zostawiła dla siebie. Moi rodzice są już starsi i bardzo religijni, więc nie zrozumieją tego, a nie chciałam też, żeby wszyscy w okolicy o nas gadali (...).

Pierwsza, emocjonalna reakcja rodzica daje dziecku informację zwrotną dotyczącą akceptacji lub odrzucenia jego reprezentacji tożsamościowej. W efekcie dochodzi do dalszej rozmowy, gwałtownej wymiany zdań lub zawieszenia komunikacji na bliżej nieokreślony czas.

\section{Praca nad doświadczeniem w kontekście napięć emocjonalnych}

W trakcie kolejnych dni, tygodni lub miesięcy rodzice próbują poradzić sobie z przeżywanym konfliktem: zakorzenionymi w ich światopoglądzie uprzedzeniami 
oraz miłością do swojego dziecka. Doświadczają burzliwego procesu mentalnego pracy nad nowym doświadczeniem. Wracają do rutynowych aktywności oraz komunikacji z dzieckiem, równocześnie tocząc wewnętrzną walkę. Przeżywają kryzys, który wymaga reorganizacji aktywności. Uświadamiają sobie, że wiedza, którą posiadają na temat nienormatywnej orientacji seksualnej i/lub tożsamości płciowej, jest niewystarczająca, a w dodatku stygmatyzująca. W związku z tym poszukują informacji m.in. na temat ich przyczyn, równocześnie chcąc zrzucić $\mathrm{z}$ siebie piętno złego rodzica, a z dziecka dewianta.

(...) Zaczęłam szukać informacji na stronach internetowych. Zastanawiałam się skąd się to [homoseksualność - przyp. aut.] bierze i czy jest to moja wina (...). Dowiedziałam się dobrych i złych rzeczy. Właściwie każdego wieczora szukałam czegoś nowego. Wydawało mi się, że już wszystko przeczytałam, ale szukałam dalej. (...) Pod artykułami były komentarze i oczywiście cały hejt się tam wylewał. Nie mogłam pogodzić się z tym, że oni takie okropne rzeczy piszą o osobach takich, jak moja córka. Wiedziałam, że to nie jest prawda. Ona jest mądrą i dobrą osobą (...).

Zaczynają traktować swoje dziecko jak eksperta w zakresie zgłębianego zagadnienia. W zamian otrzymują odpowiedzi na swoje pytania, materiały przygotowywane przez organizacje wspierające osoby LGBT+ lub kontakt do ludzi w nich działających (psychologów, terapeutów, aktywistów). Wraz ze wzbogacaniem zasobów wiedzy następuje redefinicja kategorii normy w odniesieniu do seksualności czy płci. Narasta też niezgoda na rozpowszechnianie przez poszczególne osoby czy media krzywdzących stereotypów, które wywołują negatywne reakcje społeczne, a także przejawy dyskryminacji mniejszości, którą uosabia własne dziecko.

(...) Zaczęły mi przeszkadzać żarty moich kolegów z pracy o osobach homoseksualnych. Bolało mnie, kiedy tego słuchałam, ale nie miałam jeszcze wystarczająco dużo odwagi w sobie, żeby przeciwstawić się im (...).

Rodzice zaczynają postrzegać swoje dziecko wielowymiarowo, nie koncentrując się już tylko na sferze jego seksualności lub płci. Konfrontują się ze swoimi oczekiwaniami, zauważają też alternatywne rozwiązania.

(...) Poczułem ukojenie, kiedy zdałem sobie sprawę, że w tym wszystkim nie chodzi o seks. Chodzi o to, żeby nie była w życiu sama, żeby była kochana (...).

(...) Gdzie jest napisane, że w zamian za wikt i opierunek ma mi dostarczyć wnuki? Najlepiej chłopczyka i dziewczynkę. Nie ma takiego kontraktu. (...) Jak kiedyś będzie chciała mieć dzieci, to nic nie stoi na przeszkodzie i są różne możliwości, np. in vitro (...). W moim dziecku nic się nie zmieniło. Nadal jest bardzo zdolna, uczynna, ma mnóstwo przyjaciół, jest lubiana, ma swoje pasje i marzenia (...). 


\section{(Współ)odczuwanie i (współ)rozumienie doświadczenia}

Niektórzy rodzice poprzestają na weryfikacji swojej dotychczasowej wiedzy za pośrednictwem Internetu, inni poszukują sposobów na nawiązanie kontaktu z ludźmi w podobnej jak oni sytuacji. Jest to podyktowane potrzebą dzielenia się swoimi przeżyciami i wątpliwościami, uzyskania nowych informacji oraz uprawomocnienia tych już zebranych, poszukiwaniem sprawdzonych rozwiązań czy rekomendowanych specjalistów $\mathrm{w}$ danej dziedzinie. Publiczny coming out jest związany z silnym przeżyciem emocjonalnym.

(...) Było mi bardzo ciężko i potrzebowałam rozmowy z innymi osobami, które przeżywają to, co ja. Wiele lat temu nie było żadnych grup wsparcia dla rodziców. Przypadkiem znalazłam informację, że psycholog, który wspiera młodzież, organizuje też spotkania dla rodziców. Trochę to trwało, zanim się zdecydowałam pójść. Byłam przerażona, kiedy okazało się, że jestem sama. Na szczęście później przyszła jeszcze jedna mama. Utrzymuję z nią kontakt do dziś (...).

Zazwyczaj o nienormatywności dziecka w pierwszej kolejności dowiadują się członkowie jego najbliższej rodziny (rodzice, rodzeństwo). Niekiedy osoba LGBT+ ujawnia się samodzielnie, a innym razem mówi tylko jednemu rodzicowi i prosi o poinformowanie kolejnych osób. Jest to zależne m.in. od relacji panujących $\mathrm{w}$ rodzinie, często też wiąże się z obawą przed niezrozumieniem i odrzuceniem. W ten sposób rodzic zaczyna dokonywać własnych coming outów przed rodziną, przyjaciółmi, znajomymi czy współpracownikami, podejmując decyzję, komu i w jakiej sytuacji chce się ujawnić. Sytuacja ta wielokrotnie powtarza się, a w zależności od rozmówcy generuje określony poziom stresu i lęku. Niekiedy jest też przyczyną nieporozumień z dzieckiem, które ma pretensje o to, że jego prywatne sprawy stają się publiczną tajemnicą. Z czasem początkowy lęk przed reakcją innych osób ustępuje i coming out staje się sposobem na zweryfikowanie grona osób, z którymi będzie podtrzymywana dalsza relacja.

(...) Na początku bardzo przeżywałam za każdym razem, kiedy miałam komuś powiedzieć, że moje dziecko jest inne. Bałam się co o mnie pomyślą, czy go nie odrzucą albo odwrócą się od całej naszej rodziny. (...) Do dziś już wiele razy mówiłam o tym i jest mi dużo łatwiej. Doszłam też do wniosku, że nie wszystkim muszę się tłumaczyć, zwłaszcza jak to nie jest dla mnie ważna osoba. Teraz obcym mówię, kiedy chcę, żeby zastanowili się nad bzdurami, które powtarzają, ale nie zawsze mam na to siłę. (...) To co ludzie mówią pośrednio o moim dziecku, jest też dla mnie sygnałem czy powinnam nadal utrzymywać z nimi kontakt (...).

\section{Usensownienie aktywności}

Poszukujący, otwarty i akceptujący rodzic może budować bliskie relacje ze swoim dzieckiem, towarzyszy mu, poznaje jego znajomych lub partnera/partnerkę. Jeśli 
dziecko należy do organizacji wspierającej osoby LGBT+, jest też zapraszany do udziału w spotkaniach. Ma wówczas możliwość poznać historie młodzieży i dorosłych, którzy opowiadają o więziach z własnymi rodzicami. Utwierdza się wówczas w przekonaniu, że postępuje właściwie.

(...) To spotkanie mną wstrząsnęło. Myślałam, że to jest normalne i nie robię nic nadzwyczajnego, że wspieram moje dziecko. Nasłuchałam się tam o wyrzucaniu $\mathrm{z}$ domu i przemocy. Nie zdawałam sobie sprawy ze skali tego zjawiska (...).

Nieliczni rodzice odkrywają w sobie potrzebę podjęcia określonych aktywności w odpowiedzi na obserwowaną przez siebie krzywdę, jakiej doświadczają osoby LGBT+. Rozumieją przeżycia rozdzielanych przez uprzedzenia rodzin, chcą wspierać wszystkie osoby LGBT+ oraz rozmawiać z ich rodzicami, dzieląc się swoją historią. Stają się sojusznikami społeczności i rzecznikami już nie tylko swoich dzieci, którzy kierują się trudną do podważenia rodzicielską miłością.

(...) Spotkaliśmy się [rodzice osób LGBT+ - przyp. aut.] kiedyś prywatnie w kawiarni i doszliśmy do wniosku, że trzeba zacząć działać. W ten sposób narodził się pomysł stowarzyszenia. Razem łatwiej nam było organizować wsparcie dla innych rodziców, ale też informować społeczeństwo i stawać w obronie naszych dzieci (...).

W ten sposób zorganizowana aktywność rodziców nabiera wymiaru społeczno-pedagogicznego, ponieważ korzystając z indywidualnych oraz zbiorowych sił aktywnie przekształcają rzeczywistość, równocześnie wzmacniając innych i zachęcając ich do współtworzenia warunków życia wolnych od uprzedzeń czy praktyk dyskryminacyjnych.

\section{Zakończenie}

Proces transformacji analizowany w kontekście relacji rodzic - dziecko LGBT+ obejmuje przeobrażenia samych rodziców, a także aktywności, jakie podejmują i pod wpływem których się zmieniają. W narracjach rekonstruują oni swoje doświadczenia, opisując przebieg zdarzeń, równocześnie wyjaśniają sposób rozumienia rzeczywistości, przybliżają motywy podejmowanych decyzji i swojego postępowania czy towarzyszące im emocje. Wracają do kwestii istotnych dla nich w przeszłości oraz tych, które przypomniane aktualnie, wywołały refleksję. Wszystkie elementy historii splatają się ze sobą, ale kolejno odtwarzane odkrywają przed samym narratorem swój sens.

Ważne miejsce w ich biografii zajmowało wydarzenie, które zapoczątkowało szereg zmian w nich samych i ich życiu, dla niektórych osób tak istotne, że dzielili swoje życie na dwa okresy: przed i po coming oucie dziecka. Stał się on punktem 
zwrotnym zaburzającym podejmowane dotychczas rutynowe czynności, wymagającym redefinicji sytuacji i pracy nad doświadczeniem.

Coming out zwykle wywoływał szok i szereg towarzyszących mu intensywnych emocji, wyrażających się w spontanicznych reakcjach. Niekiedy impulsywne zachowanie zostało stłumione przez myśl, że to może zranić dziecko, co jednak nie powstrzymało gwałtownych przeżyć. Dominujące w tym czasie negatywne uczucia, które wynikały ze zinternalizowanych stereotypów i uprzedzeń, stały w sprzeczności ze zdefiniowaną i praktykowaną rolą rodzica. W konsekwencji afektów (poczucia winy, wstydu, lęku przed oceną albo miłości do dziecka czy złości na przypisane mu piętno) pojawiło się zaangażowanie w różne aktywności: unieważnianie nowej informacji o dziecku i powrót do rutynowych czynności lub poszukiwanie wiedzy, która zredukuje napięcie emocjonalne. W dłuższej perspektywie czasu brak działania (trwanie) powodował narastanie trudności i pogarszanie się relacji z dzieckiem, które wycofywało się z kontaktu, ponieważ nie odczuwało akceptacji swojego obrazu tożsamościowego. Znacznie częściej jednak konflikt uczuć wywoływał potrzebę uzupełnienia i weryfikacji posiadanej wiedzy, która może stać się uzasadnieniem dla działania. Z początkowego chaosu informacyjnego wyłaniał się obraz odmienny od upowszechnianego przez stereotypy i uprzedzenia, legitymizowany przez autorytety naukowe oraz osoby świadczące swoim doświadczeniem. W zestawieniu z miłością do własnego dziecka i sposobem pojmowania swojej roli rodzica skutkowało to sprzeciwem wobec działań dyskryminujących, również w sferze języka oraz aktywną ochroną dziecka. Z czasem aktywności przyjmowały coraz bardziej zorganizowaną formę działań na rzecz całej społeczności osób LGBT+.

W rekonstruowanym procesie transformacji można zidentyfikować powiązane ze sobą przeobrażenia w zakresie uznanej wiedzy i sposobu rozumienia rzeczywistości, odczuwanych emocji, waloryzowanych pozytywnie lub negatywnie, a także podejmowanych aktywności ukierunkowanych na unikanie, wycofywanie się lub dążenie do celu. Związki i napięcia między aktywnościami mentalnymi, afektywnymi oraz performatywnymi powodują ich splatanie się, a przez to są trudne do uchwycenia dla zaangażowanego w toczące się zdarzenia rodzica. Nie zawsze jest to zatem proces uświadomiony, jednak zapewnia ciągłość i integralność doświadczeń rodziców osób LGBT+, czyni je dla nich zrozumiałymi, komunikowalnymi i nadaje im sens.

\section{Bibliografia}

Barbier J.-M. (2015) Nowe wyzwania dla badań w naukach o wychowaniu: perspektywa działania/aktywności, tłum. G. Karbowska, „Nauki o Wychowaniu. Studia Interdyscyplinarne", nr 1, s. 60-72.

Barbier J.-M. (2016) Leksykon analizy aktywności. Konceptualizacje zwyczajowych pojęć, tłum. E. Marynowicz-Hetka, Łódź, Wydawnictwo Uniwersytetu Łódzkiego. 
Barbier J.-M. (2020) Konstruowanie aktywności i podmiotu w aktywności - wzajemne powiq̨zania, tłum. G. Karbowska w: Pedagogika społeczna. Spotkania, trwanie i zmienność, pogranicza, A. Walczak, L. Telka, M. Granosik (red.), Łódź, Wydawnictwo Uniwersytetu Łódzkiego, s. 223-230.

Baxter L. A. (2004) Relationships as dialogues, „Personal Relationships”, nr 11, s. 1-22, https://doi.org/10.1111/j.1475-6811.2004.00068.x

Ben-Ari A. (1995) The discovery that an offspring is gay: Parents', gay men's, and lesbians' perspectives, „Journal of Homosexuality”, nr 30 (1), s. 89-10, https:// doi.org/10.1300/J082v30n01_05

Bernstein B. E. (1990) Attitudes and issues of parents of gay men and lesbians and implications for therapy, "Journal of Gay \& Lesbian Psychotherapy”, nr 1 (3), s. 37-53, https://doi.org/10.1300/J236v01n03_03

Broad K. L. (2002) Social movement selves, „Sociological Perspectives”, nr 45 (3), s. 317-336, https://doi.org/10.1525/sop.2002.45.3.317

D’Augelli A. R. (2005) Stress and adaptation among families of lesbian, gay, and bisexual youth: Research challenges, „Journal of GLBT Family Studies”, nr 1, s. 115-135, https://doi.org/10.1300/J461v01n02_07

D’Augelli A. R., Hershberger S. L., Pilkington N. W. (1998) Lesbian, gay, and bisexual youths and their families: Disclosure of sexual orientation and its consequences, „American Journal of Orthopsychiatry", nr 68, s. 361-371, https://doi.org/10.1037/ h0080345

D'Augelli A. R., Patterson C. J. (2001) Lesbian, gay, and bisexual identities and youth. Psychological perspectives, New York, Oxford University Press.

DeVine J. L. (1984) A systemic inspection of affectional preference orientation and the family of origin, "Journal of Social Work \& Human Sexuality”, nr 2, s. 9-17, https://doi.org/10.1300/J291V02N02_02

Eliason M. J. (1997) The prevalence and nature of biphobia in heterosexual undergraduate students, „Archives of Sexual Behavior”, $\mathrm{nr}$ 26, s. 317-326, https:// doi.org/10.1023/A:1024527032040

Eliason M., Raheim S. (1996) Categorical measurement of attitudes about lesbian, gay, and bisexual people, "Journal of Gay \& Lesbian Social Services”, nr 4, s. 51-65, https://doi.org/10.1300/J041v04n03_03

Elo S., Kyngäs H. (2008) The qualitative content analysis process, „Journal of Advanced Nursing", nr 62 (1), s. 107-115, https://doi.org/10.1111/j.1365-2648.2007.04569.x

Fields J. (2001) Normal queers: Straight parents respond to their children's coming out, „Symbolic Interaction”, nr 24 (2), s. 165-187, https://doi.org/10.1525/si.2001.24.2.165 
Fish T., Rye B. (1991) Attitudes toward a homosexual or heterosexual persons with AIDS, "Journal of Applied Social Psychology", $\mathrm{nr}$ 21, s. 651-667, https://doi.org/10.1111/j.1559-1816.1991.tb00541.x

Glaser B. G., Strauss A. L. (1967) The Discovery of Grounded Theory. Strategies for Qualitative Research, Chicago, Aldine Publishing Com.

Gordon A., Meyer I. (2007) Gender nonconformity as a target of prejudice, discrimination and violence against LGB individuals, „Journal of LGBT Health Research", $\mathrm{nr} 3$, s. 55-71, https://doi.org/10.1080/15574090802093562

Górska P., Mikołajczak M. (2015) Tradycyjne i nowoczesne uprzedzenia wobec osób homoseksualnych $w$ Polsce w: Uprzedzenia $w$ Polsce, A. Stefaniak, M. Bilewicz, M. Winiewski (red.), Warszawa, Wydawnictwo Liberi Libri, s. 179-206.

Graneheim U. H., Lindgren B. M., Lundman B. (2017) Methodological challenges in qualitative content analysis. A discussion paper, „Nurse Education Today”, $\mathrm{nr} 56$, s. 29-34, https://doi.org/10.1016/j.nedt.2017.06.002

Heatherington L., Lavner J. A. (2008) Coming to terms with coming out: review and recommendations for family systems-focused research, "Journal of Family Psychology”, t. 22, nr 3, s. 329-343, https://doi.org/10.1037/0893-3200.22.3.329

Hermanns H. (1987) Narrative Interview: A New Tool for Sociological Field Research w: Approaches to the Study of Face-to-Face Interaction, Z. Bokszański, M. Czyżewski (red.), „Folia Sociologica”, nr 13, Łódź, Wydawnictwo Uniwersytetu Łódzkiego, s. 43-56.

Kimmel M. S. (2009) Masculinity as homophobia. Fear, shame, and silence in the construction of gender identity w: Sex, gender, and sexuality, A. Ferber, K. Holcomb, T. Wentling (red.), New York, Oxford University Press, s. 58-70, https://doi.org/ 10.4135/9781452243627.n7

Kübler-Ross E. (1969) On death and dying, New York, Macmillan.

LaSala M. C. (2000) Lesbians, gay men, and their parents: Family therapy for the coming out crisis, „Family Process”, nr 39, s. 67-81, https://doi.org/10.1111/j.15455300.2000.39108.x

McConahay J. B. (1986) Modern racism, ambivalence, and the modern racism scale w: Prejudice, discrimination and racism. Theory and research, S. L. Gaertner, J. Dovidio (red.), New York, Academic Press, s. 91-126.

Muller A. (1987) Parents matter: Parents' relationships with lesbian daughters and gay sons, United States, Naiad Press.

Park C. L. (2010) Making sense of the meaning literature: An integrative review of meaning making and its effects on adjustment to stressful life events, „Psychological Bulletin", nr 136 (2), s. 257-301, https://doi.org/10.1037/a0018301 
Raja S., Stokes J. (1998) Assessing attitudes toward lesbians and gay men. The modern homophobia scale, „International Journal of Sexuality and Gender Studies”, nr 3, s. 113-134, https://doi.org/10.1023/A:1023244427281

Robinson B. A. (2018) Conditional families and lesbian, gay, bisexual, transgender, and queer youth homelessness: Gender, sexuality, family instability, and rejection, "Journal of Marriage and Family", nr 80 (2), s. 383-396, https://doi.org/10.1111/jomf.12466

Saltzburg S. (2004) Learning that an adolescent child is gay or lesbian. The parent experience, „Social Work”, nr 49, s. 109-118, https://doi.org/10.1093/sw/49.1.109

Savin-Williams R. C. (1989) Coming out to parents and self-esteem among gay and lesbian youths, "Journal of Homosexuality", nr 18 (1-2), s. 1-35, https://doi.org/ 10.1300/J082v18n01_01

Savin-Williams R. C., Dubé, E. M. (1998) Parental reactions to their child's disclosure of a gay/lesbian identity, „Family Relations. An Interdisciplinary Journal of Applied Family Studies", nr 47 (1), s. 7-13, https://doi.org/10.2307/584845

Schütze F. (2008) Biography Analysis on the Empirical Base of Autobiographical narratives: How to analyse autobiographical narrative interviews. Part one, „European Studies on Inequalities and Social Cohesion", nr 1/2, s. 153-242.

Strauss A. L. (1969) Transforming of Identity w: A. L. Strauss, Mirrors and Masks. The Search for Identity, San Francisco, The Sociology Press, s. 89-118.

Švab A., Kuhar R. (2014) The Transparent and Family Closets. Gay Men and Lesbians and Their Families of Origin, „Journal of GLBT Family Studies”, t. 10, nr 1-2, s. 15-35, https://doi.org/10.1080/1550428X.2014.857553

Worth $\mathrm{H}$. (2003) The myth of the bisexual infector?, "Journal of Bisexuality", nr 3, s. 69-88, https://doi.org/10.1300/J159v03n02_05

Worthen M. G. F. (2012) An Argument for Separate Analyses of LGBT+, „Sex Roles”, nr 68 (11-12), s. 703-723, https://doi.org/10.1007/s11199-012-0155-1

\section{Transformations in Interactions: the Example of the Relationship between Parents and LGBT+ Children}

\section{Summary}

The aim of this paper is to reconstruct the transformation process that takes place in the relationship between a parent and a child with non-normative sexual orientation or gender identity (LGBT+). Transforming oneself and one's reality takes place in the 
course of undertaken activities. Thus, the identification of mental, affective and performative activities, as well as the relationships between them, allows for the recreation of the tensions that appear between knowledge, information, worldview, and emotions, feelings and actions taken.

The study involved parents of LGBT+ people from Poland (28 people in total), who were selected in accordance with the snowball procedure, while taking into account the strategy of minimum and maximum contrast, resulting from the theoretical selection of the sample. The empirical material (autobiographical narratives) was collected with the use of the narrative interview technique (F. Schütze), and then elaborated in the course of qualitative inductive thematic analysis.

The interpretative framework of this paper is the concept of transformation of the subject in the course of undertaken activity (Barbier). Experiences communicated in narratives refer to the transformation of activities undertaken by the subject, which simultaneously changes during and through them. In the course of creating narratives about their lives, the surveyed parents of LGBT+ people gave retrospections of the intertwined events, their activities and the accompanying emotions that initiated work on the experience.

The reconstructed weaves of mental, affective and performative activities emphasize the relationships and tensions that exist between them: (un)awareness of the child's suffering; experiencing and (with) understanding one's own suffering; emotional confrontation with ideas; working on experience in the context of emotional tensions; (co)feeling and (co)understanding experience; making sense of activity. The identified mental changes in the perception and understanding of reality, modifications of affects that dynamized the activity of the subject and activities that transform the world comprised the analysed transformation process in interactions.

\section{Transformations dans les interactions : l'exemple des relations entre parents et enfants (LGBT+)}

\section{Résumé}

Le but de cet article est de reconstruire le processus de transformation qui a lieu dans les relations entre parent et enfant d'une orientation sexuelle ou d'une identité de genre non normative (LGBT+). Les transformations de soi et du réel se développent au cours des activités. L'identification des activités mentales, affectives et performatives, ainsi que les liens entre elles, permettent de reconstruire des tensions entre savoir, informations, vision du monde et émotions, sentiments et action entreprise.

Ont participé à la recherche des parents de personnes LGBT+ de Pologne, au total 28 personnes, qui ont été sélectionnées selon la procédure dite de boule de neige, en tenant compte de la stratégie du contraste minimum et maximum résultant de la sélection théorique de l'échantillon. Le matériel empirique (récits autobiographiques) a été collecté à l'aide de la technique d'entretien narratif (F. Schütze), et ensuite élaboré au cours d'une analyse inductive et qualitative. 
Le cadre interprétatif de cet article est le concept de transformation du sujet au cours de l'activité (J.-M. Barbier). Les expériences communiquées dans les récits se réfèrent à la transformation des activités entreprises par le sujet, qui changent pendant et à travers l'activité. Au cours de la construction de leurs récits de vie, les parents interrogés ont fait des rétrospections sur les événements entrelacés, sur les activités entreprises et sur les émotions les accompagnant, ce qui a souvent déclenché un travail sur l'expérience.

Les tissages reconstitués des activités mentales, affectives et performatives soulignent liens réciproques et tensions entre eux. Ce sont notamment : une (in)conscience de la souffrance de l'enfant; un éprouvé et une compréhension de sa propre souffrance ; une confrontation affective au regard de ses représentations ; un travail sur l'expérience dans le contexte de tensions émotionnelles ; une expérience de (co) ressenti et de (co) compréhension ; un effort pour donner du sens à l'activité.

Les changements mentaux identifiés l'étaient dans la perception et la compréhension du réel, dans les affects dynamisant l'activité du sujet, ils comprenaient l'analyse du processus des transformations produites en interaction.

\section{Cytowanie}

Gajek K. (2021) Transformacje $w$ interakcjach: przykład relacji między rodzicami i dziećmi LGBT+, „Nauki o Wychowaniu. Studia Interdyscyplinarne” 2(13), 186-204, https://doi.org/10.18778/2450-4491.13.12 